This PDF is a selection from a published volume from the National Bureau of Economic Research

Volume Title: Labor Markets and Firm Benefit Policies in Japan and the United States

Volume Author/Editor: Seiritsu Ogura, Toshiaki Tachibanaki and David A. Wise, editors

Volume Publisher: University of Chicago Press

Volume ISBN: 0-226-62094-8

Volume URL: http://www.nber.org/books/ogura03-1

Conference Date: January 20-23, 2000

Publication Date: January 2003

Title: Fringe Benefit Provision for Female Part-Time Workers in Japan

Author: Yukiko Abe

URL: http://www.nber.org/chapters/c10312 


\title{
Fringe Benefit Provision for Female Part-Time Workers in Japan
}

\author{
Yukiko Abe
}

\subsection{Introduction}

Japan has universal public pension and health insurance coverage. Universal health care coverage is achieved through a combination of an employer mandate and regional plans for self-employed and nonworking individuals. ${ }^{1}$ Since coverage is universal, whether one is covered is unrelated to his or her labor supply decision. However, how one is covered is closely related to his or her employment status. Workers who do not work full-time may not receive coverage through their employers. In this article, I focus on one such group of workers: women who work part-time.

Part-time work has expanded rapidly in Japan in the 1980s and 1990s. According to the Employment Status Survey (Statistical Bureau 1984, 1998), the number of female part-time and arbeit workers increased from 3.9 million in 1982 to 8.3 million in $1997 .{ }^{2}$ In light of this expansion, labor

Yukiko Abe is associate professor of economics at Asia University.

This paper is part of a project on part-time work conducted by Fumio Ohtake and the author. They thank the Ministry of Labor of Japan for permission to use microdata from the proprietary General Survey of Part-Time Workers' Conditions in 1990 and 1995. The author thanks Akira Wakisaka, David Wise, and participants in the National Bureau of Economic Research-Japan Center for Economic Research conference for helpful comments. The author is responsible for all errors. Financial support from the Japan Foundation Center for Global Partnership is gratefully acknowledged.

1. The universal public pension is administered under a similar scheme. Most salary earners are covered through employer-provided plans, whereas the self-employed and farmers are covered by the national pension program. However, unlike the health insurance system, local governments have no discretion over the structure of the national pension.

2. Arbeit workers are nonregular employees who usually work shorter hours than regular employees. When full-time students work for nonregular basis, they usually work under this title. The distinction between part-time workers and arbeit workers is not necessarily clear, 
market policies affecting part-time workers have generated increased interest. One such policy concerns social insurance participation. Social insurance programs (in this case public pension, health insurance, and employment insurance) do not require all part-time workers to enroll. Participation is only necessary for workers with sufficiently high working hours, earnings, or both. It has been pointed out that many married women working part-time do not participate in employer-provided plans, but are covered by their husbands' insurance. In this case, neither income taxes nor social security taxes are collected out of the wife's earnings, but she is still eligible for health insurance and public pension benefits through her husband's coverage. This is problematic in terms of both efficiency and equity.

This policy is distortionary because it creates work disincentives for married women. It is not equitable because a married woman will receive benefits even though she (or her husband) does not pay extra insurance premiums for her benefits. In spite of significant interest in this topic, however, social insurance participation has not been analyzed in a systematic way. In particular, some argue that participation is low because employers do not comply with the policy rules, which results in low coverage of parttimers. Others argue that "free" coverage for low-income wives discourages participation by married women.

In this paper I use microdata on part-time workers to examine enrollment patterns of female part-time workers. I examine enrollment in employment insurance (EI), ${ }^{3}$ public pensions (EP), ${ }^{4}$ and employer-provided health insurance. ${ }^{5}$ The conditions for participating in EP and employerprovided health insurance are the same (for those younger than sixty-five): Part-time workers who work thirty hours or more are required to enroll in public pension and employer-provided health insurance. ${ }^{6}$ The coverage for

but arbeit workers have less attachment to work than part-time workers in that their tenures are shorter than those of part-time workers.

3. This program provides unemployment insurance benefits.

4. Since the focus here is private-sector employees, the applicable public pension system is the employees' pension.

5. Firms with more than 500 employees often form a health insurance society (HIS). An HIS self-insures for the health care expenditures of the enrolled employees and their dependents aged sixty-nine or younger. There were about 1,800 HISs in Japan in 1999. Health care expenditures by people over seventy years old are financed under a different scheme, but HISs usually pay significant "taxes" (contributions for health services for the elderly) to finance the health care expenditures of the elderly. Each HIS sets its health insurance premium rate individually within a range set by the government. The monthly premium for an insured employee is the premium rate multiplied by his or her regular monthly earnings. Employees in smaller firms enroll in governmentally managed health insurance (GMHI). This is a large insurance group consisting of 19.1 million insured employees and 18.2 million dependents. Like the case of HISs, the GMHI self-insures the enrollees aged sixty-nine or younger.

6 . The rule actually states that if a worker works at least three fourths of the working hours of regular employees in the same establishment, he or she has to enroll in pension and employer-provided health insurance. Since working hours for regular employees are forty hours per week, the rule is often stated as such in the text. 
EI is wider: Workers who work more than twenty hours per week or earn 0.9 million yen or more have to participate in EI. ${ }^{7}$

Some previous studies argue that social insurance benefits are not provided for part-time workers due to employer noncompliance. ${ }^{8}$ However, such generalizations do not apply uniformly across categories of workers; this study finds substantial heterogeneity in participation among part-time workers. The following analysis suggests that 86 percent of married female part-time workers who work sufficiently long hours and earn more than 1.3 million yen per year participate in the three social insurance programs above. On the other hand, 83 percent of married female part-time workers with short working hours and low earnings (less than 0.9 million yen per year) do not participate. Of the 64 percent of married female part-time workers who fall between these two groups - working twenty to thirty hours per week, earning $0.9-1.3$ million yen or both -43 percent participated in employer-provided plans in 1995. A more detailed analysis of these enrollment patterns is presented below.

\subsection{Overview of the EI, EP, and Health Insurance Systems in Japan}

\subsubsection{Participation Rules for Social Insurance Programs}

The rules for participating in social insurance programs are summarized in table 12.1. The Employer Side and Worker Side columns show the requirements imposed on employers and workers, respectively. A number 1 in either of the Employer Side columns indicates that the employer must offer benefits to the specified class of employee; a 1 in the Worker Side column indicates that a worker belonging to the specified class of employee cannot be considered a dependent of another family member (for the purposes of social insurance plans) and must enroll in the social insurance plan by herself.

A worker with weekly hours more than three-fourths those of regular employees in the same establishment is required to participate in EP and employer-provided health insurance. However, if a husband participates in EP and employer-provided health insurance through his employer, his wife can receive basic pension and health care benefits as a dependent of her husband, as long as her earnings are less than 1.3 million yen per year and

7. This is the enrollment condition for EI for short-hour workers that was introduced in 1989. Those who work more than thirty hours per week enroll in EI for regular workers. The benefits of the two differ, but the premium rate is the same. Effective in April of 2001, the threshold for the EI enrollment ( 0.9 million yen) was repealed. Therefore, under the system at the point of this writing (2002), the cells stratified by the 0.9 million yen threshold do not exist any more. Table 12.4 shows the rules at the point of the data used in the analysis (1990 and 1995).

8. Takayama (1997) notes that "part-time workers who earn 1.3 million yen have to enroll in national pension insurance and pay the premium by themselves" (emphasis added; 135). 
Table 12.1 Conditions for Enrollment in Social Insurance

\begin{tabular}{|c|c|c|c|c|c|c|}
\hline & \multirow{2}{*}{$\begin{array}{c}\text { Cell } \\
\text { Number }\end{array}$} & \multirow{2}{*}{$\begin{array}{l}\text { Weekly } \\
\text { Hours }\end{array}$} & \multirow{2}{*}{$\begin{array}{c}\text { Annual } \\
\text { Earnings }\end{array}$} & \multicolumn{2}{|c|}{$\begin{array}{c}\text { Employer } \\
\text { Side }^{\mathrm{a}}\end{array}$} & \multirow{2}{*}{$\begin{array}{c}\text { Worker Side } \\
\text { EPH }\end{array}$} \\
\hline & & & & EPH & EI & \\
\hline \multirow[t]{9}{*}{1990} & 1 & $<22$ & $<90$ & & & \\
\hline & 2 & $<22$ & $90-110$ & & & \\
\hline & 3 & $<22$ & $110+$ & & & 1 \\
\hline & 4 & $22-33$ & $<90$ & & & \\
\hline & 5 & $22-33$ & $90-110$ & & 1 & \\
\hline & 6 & $22-33$ & $110+$ & & 1 & 1 \\
\hline & 7 & $33+$ & $<90$ & 1 & & \\
\hline & 8 & $33+$ & $90-110$ & 1 & 1 & \\
\hline & 9 & $33+$ & $110+$ & 1 & 1 & 1 \\
\hline \multirow[t]{9}{*}{1995} & 1 & $<22$ & $<90$ & & & \\
\hline & 2 & $<22$ & $90-110$ & & & \\
\hline & 3 & $<22$ & $110+$ & & & 1 \\
\hline & 4 & $22-33$ & $<90$ & & & \\
\hline & 5 & $22-33$ & $90-110$ & & 1 & \\
\hline & 6 & $22-33$ & $110+$ & & 1 & 1 \\
\hline & 7 & $33+$ & $<90$ & 1 & & \\
\hline & 8 & $33+$ & $90-110$ & 1 & 1 & \\
\hline & 9 & $33+$ & $110+$ & 1 & 1 & 1 \\
\hline
\end{tabular}

Notes: An entry of 1 on the firm side means enrollment is required. An entry of 1 on the worker side means that the worker cannot qualify as a dependent of another family member and thus must enroll in social insurance individually.

$\mathrm{EI}=$ employment insurance

$\mathrm{EPH}=$ employees' pension and Health Insurance

${ }^{\text {a }}$ Must enroll.

${ }^{\mathrm{b} C a n n o t}$ qualify as a dependent.

less than half of her husband's earnings. For EI, an employee working more than twenty hours per week and earning more than 0.9 million yen per year or more is required to participate.

In principle, employers who meet the employer-side conditions must force workers to participate in the social insurance programs, irrespective of their worker-side conditions. For example, if a married, female part-time worker works thirty-five hours per week and earns 1.2 million yen, the employer must enroll her in EP and employer-provided health insurance, even though she could claim benefits from her husband's coverage. Nonetheless, the worker-side conditions may affect participation, even conditional on hours and earnings. Most importantly, as the following analysis confirms, many female part-time workers satisfy some conditions but not others. Most of them work reasonably long hours, but their earnings remain below the threshold for participation in health and EP insurance.

Based on the rules described in table 12.1, I construct nine cells defined 
by pairs of ranges in weekly hours and annual earnings. They are numbered from one to nine (the second column of table 12.1). The cells differ by whether they meet the conditions for enrollment. For example, workers in cell 1 (the top row for each year) do not satisfy the enrollment conditions for any of the insurance programs considered here; workers in cell nine satisfy hours and earnings conditions for participating in all of the programs. In the analysis below, I classify the observations in my sample into these cells. It is important to bear in mind that measurement error in both hours and earnings might cause misclassification.

\subsubsection{Costs Associated with Social Insurance Programs}

Participation in social insurance programs requires contributions by both the employer and the employee. For some employers there are costs associated with paying for the benefits. However, benefits are paid out of collected premiums (and accrued interest), so they are not necessarily at a cost to employers. In 1990-1995 (the period for the data used in this paper), employees' pension funds (EPFs) and health insurance societies (HISs) were required to pay benefits, and the value of contributed premiums are not equal for some workers. Most importantly, it is expected that costs will be higher for older workers, although the insurance premium rate does not depend on age. ${ }^{9}$

\section{Insurance Premium Costs}

Social insurance enrollees have to contribute a fixed proportion of their regular monthly earnings as insurance premiums. The premium rate is 17.35 percent for EP (for 1996-2002), approximately 8.5 percent for employer-provided health insurance, and 1.15 percent for EI (for 1993-2000). In nominal terms, firms pay half of the EP insurance premium and also approximately half of the employer-provided health insurance premium. For $\mathrm{EI}$, the premium rate is 0.75 percent for firms and 0.4 percent for workers. Regular monthly earnings are approximately equal to monthly earnings if the latter fall within government-specified lower and upper bounds. ${ }^{10}$ For $\mathrm{EP}$, the lower bound is 92,000 yen per month and the upper bound is 590,000 (figures are for 1994-2000). For health insurance, the lower bound is 92,000 yen per month and the upper bound is 980,000 (figures are for 1994-2000). Those who earn less than the lower bound pay an insurance premium and receive EP benefits as if their earnings were equal to the lower bound. Similarly, the premium amount and EP benefits for employees with earnings above the upper limit are based on the value of the upper bound. ${ }^{11}$

9. For pensions, this is the same concept as the low marginal tax rate for old employees, as pointed out by Feldstein and Samwick (1992).

10. Bonus payments are not included in regular monthly earnings.

11. The upper bound is similar to the maximum taxable earnings in the U.S. Social Security program. 


\section{Costs Associated with Paying Benefits}

Most studies of costs of social insurance to the firm focus exclusively on the firm's insurance premium payments. They treat these as taxes on labor income and argue that firms are reluctant to enroll part-time workers in social insurance programs because of these taxes. ${ }^{12}$ However, there are important additional costs to the firm arising from benefit payments to the firm's enrollees and retirees.

Under the current system, firms with EPFs or HISs directly pay a part of benefits to their enrollees. ${ }^{13}$ The EPFs pay the earnings-related portion of the EP benefits and corporate pensions to retirees. The HISs self-insure health care costs for enrollees less than seventy years old. The required expenditure for these benefits may differ substantially across individuals. On the other hand, premium rates for EP and employer-provided health insurance are not allowed to vary across employees. Under such systems, firms with EPSs or HISs will care about whom they include in their insurance plans. For example, if a firm hires a sick worker on a full-time basis, the health care expenditure of that worker may exceed his or her contributions (insurance premiums). The welfare of other members of the HIS would fall because of his or her enrollment.

Small firms are not allowed to form HISs or EPFs. Benefits for enrollees are paid by government agencies (the Social Insurance Agency [EP] or the Governmentally Managed Health Insurance (GMHI). So once employers pay insurance premiums for their employees to the government, the government will pay all benefits to employees. Firms do not have to worry about the costs of paying benefits.

In principle, if the costs of paying benefits are shifted to insurance premiums (with higher-cost employees paying higher premiums), social insurance participation should not be affected by worker characteristics that are associated with higher benefits. If shifting is possible, firms will be indifferent between hiring high-benefit workers and low-benefit workers (assuming the only difference between the two groups is social insurance costs). However, full shifting means wages depend on health status. As explained above, the premium rate is not allowed to vary across workers. It would probably be difficult to fully shift the costs needed to pay benefits onto wages. In the appendix, the cost structure of benefit payments of large firms is discussed in more detail.

12. These arguments ignore the fact that a portion of firms' taxes may be shifted to employees in the form of lower wages.

13. Strictly speaking, the entities that pay benefits to a firm's employees and retirees are the HIS (for health care) and the EPF (for the form of corporate pension relevant here), which are distinct from the firm. However, since these organizations handle all the health care and corporate pension payouts to the employees and retirees of the firm, I treat them as the same entity as the firm. 


\subsubsection{Predictions of the Enrollment Patterns of Female Part-Time Workers}

In light of the cost structure of social insurance benefits, I look for evidence of two effects on participation behavior: the marital status effect and the age effect.

\section{Marital Status Effect}

As shown in table 12.1, marital status is not included in the criteria for participation in any of the three insurance programs. Nevertheless, the fact that married women could receive benefits through their spouse's coverage may reduce participation if their earnings and hours do not exceed the statutory thresholds. Furthermore, if noncompliance exists, it is most likely to occur in cases where workers lose little from nonenrollment. For these reasons, married women should be less likely to participate in EP and health insurance programs than single women. However, differences across marital status should be small for participation in employment insurance.

\section{Age Effect}

Older workers are less likely to participate in EP and health insurance, especially in large firms. This is because large firms are more likely to form EPFs, HISs, or both, so they are more likely to be concerned with the costs of paying benefits, which are higher for older workers. Hence, employers are more reluctant to include old part-time workers in their firm-based plans.

\subsubsection{Comparison with the U.S. System}

The social security systems in the United States and Japan differ in many ways. This section summarizes the differences that are relevant for women with low earnings - the focus of this paper.

First, under the Japanese system, enrollment in EP (the counterpart of U.S. Social Security) is tied to enrollment in employer-provided health insurance for private-sector wage and salary earners. Enrollment in EP means that the employee is eligible for health care benefits. For 1997-2002, if a married woman has her own coverage, the coinsurance rate is 20 percent; ${ }^{14}$ if she is covered by her husband's insurance, the coinsurance rate is 30 percent. This is an important difference from the United States, where paying payroll tax is not directly related to the employee's health insurance coverage.

Second, most private-sector employees are subject to paying payroll

14. Before 1997, if the wife had her own coverage through her employer, the coinsurance rate for outpatient expense was 10 percent. It rose to 20 percent in 1997. It is scheduled to be 30 percent (so there is no advantage for having own coverage as opposed to being covered as a dependent) after April 2003. 
taxes in the United States, whereas in Japan, low-income employees are exempt from paying social security taxes. In the United States, low-income married women are likely to claim social security benefits as their husbands' dependents, so their labor supply does not directly affect their benefit. Therefore, the net marginal social security tax rate is high for such married women (Feldstein and Samwick 1992). In Japan, low-income married women do not pay social security tax as long as their earnings are below 1.3 million yen per year (this value was effective from 1992 to 2002). Earnings of married women below this amount are untaxed by the social security system. Furthermore, if earnings are below 1 million yen per year, a part-time employee owes no social security tax, no national income tax, and no local income taxes. ${ }^{15}$ Thus, married Japanese women with earnings below the threshold face a zero marginal tax rate. ${ }^{16}$ If their annual earnings exceed 1.3 million yen, they must pay a lump-sum social security tax (so at this point their marginal tax rate is infinity). They also face a very high marginal tax rate beyond this point (over 37 percent, under certain circumstances). ${ }^{17}$ Once earnings exceed 1.619 million yen, the employment income deduction becomes more generous, so the marginal tax rate falls.

In sum, under the Japanese system, married women with sufficiently low earnings face a social security tax rate of zero. If a married woman's earnings are above the threshold but not very high compared with those of her husband, she pays social security tax but gains relatively small benefits. This latter case is similar to that of low-income married women in the United States.

15. National income tax is not imposed on employees whose earnings are 1.03 million yen or less. For earnings below 1 million yen, no local income tax is imposed.

16. Since the benefits such married women receive are the same as those enjoyed by nonworking dependent spouses, their marginal tax rate is not negative.

17. The U.S. and Japanese systems differ in the way that benefits for retired couples and surviving spouses are determined. Consider a couple in which both spouses worked in their prime (and, in Japan, the wife contributed social security tax since her earnings exceeded the threshold). Assume the husband's past earnings were much higher than that of the wife. For simplicity, assume that the husband dies earlier than the wife. In the United States, if the wife's past earnings were low, the couple receives a benefit equal to 1.5 times the husband's benefit as long as both spouses are alive. If the husband dies, the wife receives the benefit to which the husband is entitled. In Japan, as long as both spouses are alive, each spouse collects benefits based on each individual's contribution. When the husband dies, the wife can choose from one of three options: (a) three fourths of the benefit to which the husband was entitled; (b) the benefit to which the wife is entitled through her contributions; or (c) the sum of one half of the husband's entitled benefit and one half of the wife's entitled benefit. If the wife's past income was low, option (a) dominates the other two. So in Japan, the wife's contribution leads to higher benefits as long as the husband is alive. For this reason, under the Japanese system, if the wife participates in EP (the counterpart of U.S. Social Security) but her earnings are much lower than those of the husband, the wife's net social security tax rate is generally lower than the statutory rate. Furthermore, having her own coverage has the benefit of a reduced coinsurance rate in health care benefits (see above). However, the figures in the text are based on the statutory rate and do not reflect these considerations. 


\subsection{Data and Sample}

\subsubsection{Data and Summary Statistics}

The data used in this paper come from the General Survey of Part-Time Workers' Conditions (GSPWC; Ministry of Labor 1992, 1997) in 1990 and 1995. ${ }^{18}$ The GSPWC surveys those workers who are treated as part-time or arbeit workers in the workplace. Therefore, the sample includes nonregular workers who work long hours. According to the 1997 Employment Status Survey (ESS; Statistical Bureau 1998), among female part-time workers who either work less than 200 days per year on regular basis or work more than 200 days per year, 28 percent work less than twenty-two hours per week, whereas 31 percent work more than thirty-five hours per week. ${ }^{19}$ There is a large wage gap between full-time and part-time female employees. ${ }^{20}$ Therefore, defining part-time workers by number of working hours might mask significant differences between full-time workers and parttime workers with long working hours. This data set is unique in that it contains information on participation in all three insurance programs mentioned above.

The sample is restricted to female part-time workers ages twenty-five to fifty-four who (a) were not enrolled in school at the time of the survey; (b) worked at private-sector establishments in manufacturing, service, wholesale, or retail industries; (c) were classified as nonregular workers; and (d) had nonmissing earnings in the previous year. Weekly hours are calculated by multiplying hours worked per day by days worked per week, and so they are measured with error to the extent that working hours per day vary across days or working days per week vary across weeks.

Before proceeding to the analysis, a discussion on the problems with using these data for our purposes is in order. First, an employee who works for an employer for only a short duration (less than one year) is exempt from enrolling in health insurance, EP, and EI, irrespective of her hours of work. For this reason, a part-time worker may be legally exempt from participating in social insurance programs. In fact, about 8 percent of part-time workers in the sample have worked for their current employer

18. Explanations on this survey are found in the Ministry of Labor data $(1992,1997)$.

19. The proportion of less than twenty-two hours per week is higher than the figures shown in table 12.3. The possible reasons for this difference are (a) sample selection in this paper is restricted in certain ways; (b) the differences in ways that weekly hours are obtained; and (c) the GSPWC is an establishment survey whereas the ESS is a household survey (the GSPWC surveys establishments of at least five employees).

20. This is observed in the ESS. According to the survey, the median of full-time female workers' earnings is between 2.5 million and 3 million yen, whereas that of part-time and arbeit workers is between 0.5 and 1 million yen (earnings are recorded in intervals in this survey). 
for less than one year. Second, there may be measurement error in hours and earnings. In particular, the earnings figures in the survey are those for the previous calendar year, but hours are for the survey year. If labor supply behavior in the survey year differs from that of the previous year, the earnings in the two consecutive years may differ. For our purposes, if the previous year's earnings do not exceed the threshold but earnings in the survey year do, there will be a misclassification in assigning observations into the cells defined in table 12.1. However, in a cross-sectional survey, it is not easy to collect contemporaneous information on annual earnings and social insurance participation status; to get both for the same calendar year, participation status and earnings of the previous year must be recorded.

Summary statistics for the sample are presented in table 12.2. The top panel of the table shows the pattern of social insurance participation by marital status for each year. Participation in at least one program increased for both married and single women between 1990 and 1995. For married women, the proportion of those who did not participate in any of the programs declined by 12 percent, while for single women the same proportion declined by 7 percent. However, the proportion of those participating in all three of the programs stayed roughly constant for both married and single women.

There are clear differences in participation patterns between married and single women. Although 49 percent of married women did not participate in any of the programs in 1995, only 27 percent of single women fall into this category. The share of those participating in EP and health insurance is 37 percent for married women and 66 percent for single women (the sum of the EPH Only column and the All Insurance column in table 12.2). So married female part-time workers are less likely to be covered by employer-provided plans. The reasons for this are (a) married women work fewer hours than single women, and (b) among those who work a similar number of hours, married women are less likely to participate than single women. The relative importance of these factors is examined below.

The bottom panel of table 12.2 shows the distribution of social insurance participation by whether the firm requires medical checkups at the time of hiring or on a regular basis. ${ }^{21}$ Firms who have more part-time workers participating in employer-provided health insurance plans may be more concerned about the health status of their workers and so may be more likely to require medical checkups. On the other hand, whether a firm provides medical checkups should not be related to participation in EI because workers' health status is not related to the firm's burden of providing EI. The pattern shown in the panel is consistent with this hypothesis. Health

21. The provision of a medical checkup is surveyed at the establishment level. Here that information is merged with personal information. 


\begin{tabular}{|c|c|c|c|c|c|c|}
\hline & $\begin{array}{l}\text { Marital } \\
\text { Status }\end{array}$ & $\begin{array}{l}\text { No } \\
\text { Insurance }\end{array}$ & $\begin{array}{c}\text { EI } \\
\text { Only }\end{array}$ & $\begin{array}{l}\text { EPH } \\
\text { Only }\end{array}$ & $\begin{array}{c}\text { All } \\
\text { Insurance }\end{array}$ & $\begin{array}{l}\text { Sample } \\
\text { Size }\end{array}$ \\
\hline & \multicolumn{6}{|c|}{$\begin{array}{c}\text { Summary of Social Insurance Participation by Marital Status, } 1990 \\
\text { and } 1995(\%)\end{array}$} \\
\hline 1990 & Married & 60.70 & 6.76 & 1.46 & 31.07 & 13,183 \\
\hline 1990 & Single & 33.98 & 5.76 & 3.37 & 56.89 & 1,997 \\
\hline 1995 & Married & 48.78 & 14.00 & 6.89 & 30.33 & 8,420 \\
\hline \multirow[t]{2}{*}{1995} & Single & 26.63 & 7.82 & 7.55 & 58.00 & 1,538 \\
\hline & \multicolumn{6}{|c|}{ Health Checkup and Social Insurance Participation, 1995 (\%) } \\
\hline \multicolumn{7}{|l|}{$\begin{array}{c}\text { Health checkup } \\
\text { at hiring? }\end{array}$} \\
\hline \multirow[t]{2}{*}{ Yes } & Married & 31.52 & 16.42 & 3.52 & 48.55 & 3,142 \\
\hline & Single & 11.18 & 4.98 & 3.04 & 80.79 & 588 \\
\hline \multirow[t]{2}{*}{ No } & Married & 54.88 & 13.15 & 8.08 & 23.89 & 5,278 \\
\hline & Single & 32.57 & 8.91 & 9.28 & 49.24 & 950 \\
\hline \multicolumn{7}{|l|}{$\begin{array}{l}\text { Medical checkup on } \\
\text { a regular basis? }\end{array}$} \\
\hline \multirow[t]{2}{*}{ Yes } & Married & 38.41 & 17.68 & 3.88 & 40.03 & 6,522 \\
\hline & Single & 15.95 & 7.29 & 4.79 & 71.97 & 1,133 \\
\hline \multirow[t]{5}{*}{ No } & Married & 67.54 & 7.34 & 12.34 & 12.78 & 1,898 \\
\hline & Single & 44.22 & 8.68 & 12.08 & 35.01 & 405 \\
\hline & \multicolumn{6}{|c|}{ Summary Statistics, 1990 and $1995^{a}$} \\
\hline & \multicolumn{3}{|c|}{1990} & \multicolumn{3}{|c|}{1995} \\
\hline & Married & & & $\mathrm{Ma}$ & & Single \\
\hline \multicolumn{7}{|l|}{ Income in the } \\
\hline previous year & $\begin{array}{c}99.130 \\
(1.14)\end{array}$ & \multicolumn{2}{|c|}{$\begin{array}{r}131.174 \\
(3.195)\end{array}$} & \multicolumn{2}{|c|}{$\begin{array}{r}107.906 \\
(1.663)\end{array}$} & $\begin{array}{r}143.466 \\
(4.085)\end{array}$ \\
\hline \multirow[t]{2}{*}{ Earnings $>1 \mathrm{M}$} & 0.304 & \multicolumn{2}{|c|}{0.609} & \multirow{2}{*}{\multicolumn{2}{|c|}{$\begin{array}{c}0.310 \\
(0.014)\end{array}$}} & 0.663 \\
\hline & $(0.012)$ & \multicolumn{2}{|c|}{$(0.018)$} & & & $(0.03)$ \\
\hline \multirow[t]{2}{*}{ Log hourly wage } & 6.501 & \multicolumn{2}{|c|}{6.564} & \multirow{2}{*}{\multicolumn{2}{|c|}{6.663}} & 6.737 \\
\hline & $(0.008)$ & \multicolumn{2}{|c|}{$(0.014)$} & & & $(0.014)$ \\
\hline \multirow{2}{*}{ Weekly hours } & 31.299 & \multirow{2}{*}{\multicolumn{2}{|c|}{$\begin{array}{l}35.374 \\
(0.497)\end{array}$}} & & & 33.193 \\
\hline & $(0.322)$ & & & & & $(0.572)$ \\
\hline Days worked in the & & & & & & \\
\hline previous month & 20.750 & & & 19. & & 20.492 \\
\hline & $(0.166)$ & & & & & $(0.253)$ \\
\hline Age & 42.586 & & & & & 37.183 \\
\hline & $(0.135)$ & & & & $80)$ & $(0.602)$ \\
\hline Tenure & 5.230 & & & & & 4.567 \\
\hline & $(0.104)$ & & & & 18) & $(0.221)$ \\
\hline
\end{tabular}

Source: Author's calculations from the Ministry of Labor $(1992,1997)$.

Notes: The sample is restricted to private-sector employees in manufacturing, service, retail, or wholesale industries who were classified as part-time workers, were not enrolled in school, and had nonmissing earnings data. All insurance = enrollment in EP, health insurance, and employment insurance. EI Only = enrollment in employment insurance only. EPH Only = enrollment in EP and health insurance, but not in employment insurance. No insurance = enrollment in none of the three.

${ }^{\mathrm{a} S t a n d a r d ~ e r r o r s ~ a r e ~ i n ~ p a r e n t h e s i s . ~}$ 
insurance participation is higher for employers with health checkups: Forty-four percent of married female part-time workers in establishments that provide regular health checkups participated in health insurance, whereas only 25 percent participated in establishments without regular health checkups.

\subsubsection{Changes in Wage and Labor Supply from 1990 to 1995}

The second panel of table 12.2 contains summary statistics for earnings and hours by marital status. These data reveal that weekly hours decreased by about two to three hours from 1990 to 1995 , while hourly wages rose by 16 to 17 percent. The hourly wage increase is close to the growth rates of regional minimum wages during this period, which averaged 17 percent. Importantly, earnings did not grow by as much as hourly wages.

Figures 12.1 and 12.2 present the earnings distribution by marital status. As noted in previous research (Higuchi 1995; Nagase 1997; Abe and Ohtake 1997, among others), a tax-free ceiling of 1 million yen has sig-
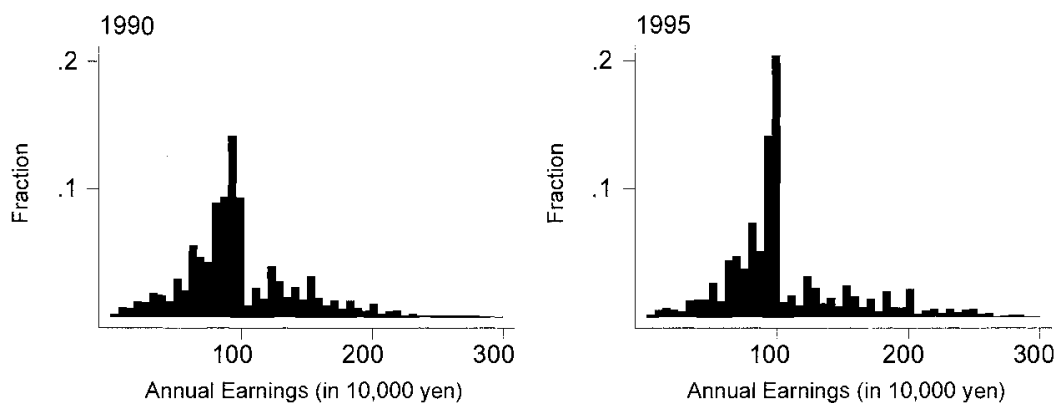

Fig. 12.1 Earnings distribution in 1990 and 1995: Married women Source: Author's calculations from the GSPWC data.
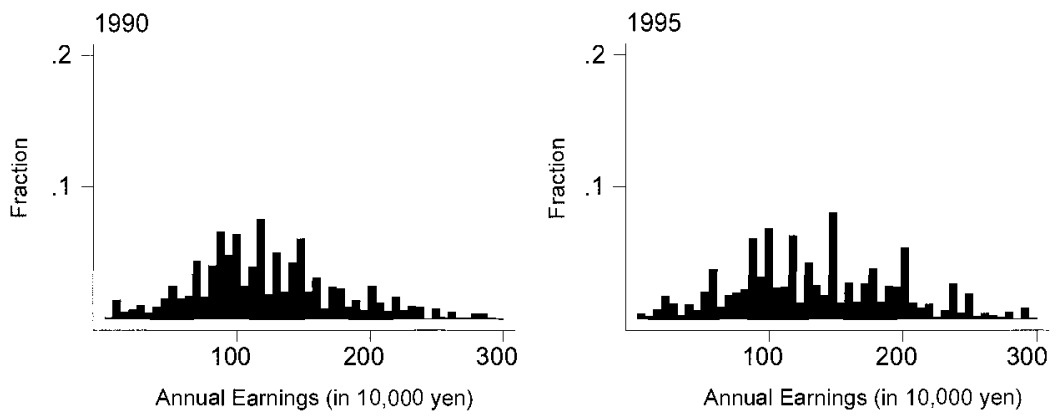

Fig. 12.2 Earnings distribution in 1990 and 1995: Single women Source: Author's calculations from the GSPWC data. 
nificant effects on the labor supply of married women. ${ }^{22}$ Married women's earnings are concentrated around 1 million yen, but earnings of single women do not exhibit such a clear concentration at that point. Furthermore, between 1990 and 1995 the earnings of married women below the 1million-yen ceiling grew. More married women earned between 0.9 and 1 million yen in 1995 than in 1990. However, the fraction earning more than 1 million yen remained unchanged at approximately 30 percent (table 12.2). In response to increases in hourly wages, married women reduced their hours, so their earnings remained constant in nominal terms.

Earnings of single women did not grow much either. In cross section, it is clear that single women's earnings are not as concentrated around 1 million yen as are earnings of married women. However, single women also reduced their hours of work from 1990 to 1995. There are several possible explanations for this reduction. First, during the period analyzed here, working hours of full-time workers were reduced from forty-four hours per week to forty hours per week. Even though there has been no legal initiative to reduce working hours of part-time workers, this regulation may have affected the hours of single female part-time workers, whose hours tend to be relatively long. Second, some single women receive transfer income, which is means tested. In that case, some of these women may have reduced their hours in response to the rise in hourly wages. The change in earnings from 1990 to 1995 can be seen in figures 12.3 and 12.4, where I plot 1990 earnings multiplied by 1.17 and actual 1995 earnings, by marital status. Since wages rose 17 percent on average, had hours remained at their 1990 levels, nominal earnings would have grown by 17 percent. However, as the figures reveal, actual 1995 earnings are concentrated in a lower range for both married and single women.

Table 12.3 shows the share of the sample in each of the nine hoursearnings cells defined by the hours and earnings thresholds for social insurance participation (see table 12.1). ${ }^{23}$ The figures in some cells are quite small. For example, the share of workers who work less than the EI minimum hours (twenty-two hours per week in 1990 and twenty hours in 1995) and earn more than the EI minimum earnings ( 0.9 million yen per year) is less than 3 percent in all four samples. As shown in table 12.3, female part-

22. For earnings up to $1,030,000$ yen, a wage earner owes no income tax. For that reason, work disincentives for a part-time worker are often described as the " 1.03 million yen ceiling," because such workers try to constrain their earnings to be below 1.03 million yen. The value of the ceiling used to be 1 million yen, so it is sometimes called the " 1 million yen ceiling" as well.

23. Higuchi (1995) is one of the earliest studies to calculate social insurance enrollment of part-time workers. He tabulates enrollment rates for health and pension insurance as well as employment insurance for married women of different earnings levels. He finds that participation rises sharply from the $0.9-0.99$ million yen range to the $1-1.09$ million yen range, and argues that firms may use 1 million yen as the threshold for enrollment in EP and health insurance, even though the threshold in the statute is 1.3 million yen. It seems that he misunderstood the statutory threshold in 1990, believing it to be 1.3 million yen, which is the threshold after 1992, even though it was in fact 1.1 million yen in 1990. 


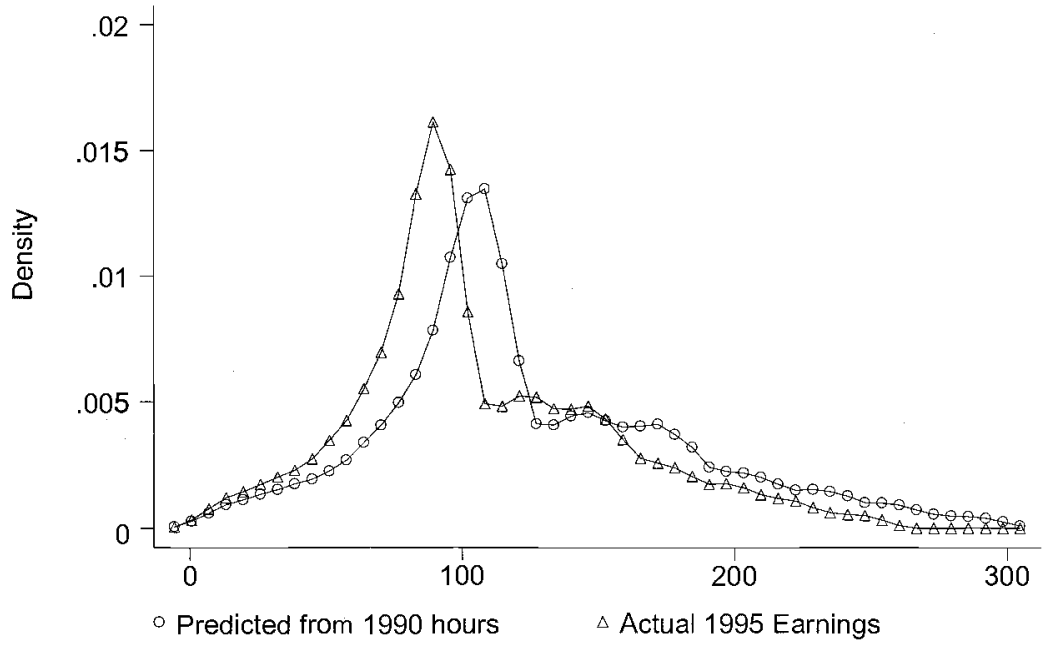

Fig. 12.3 Earnings distribution for married women

Source: Author's calculations from the GSPWC data.

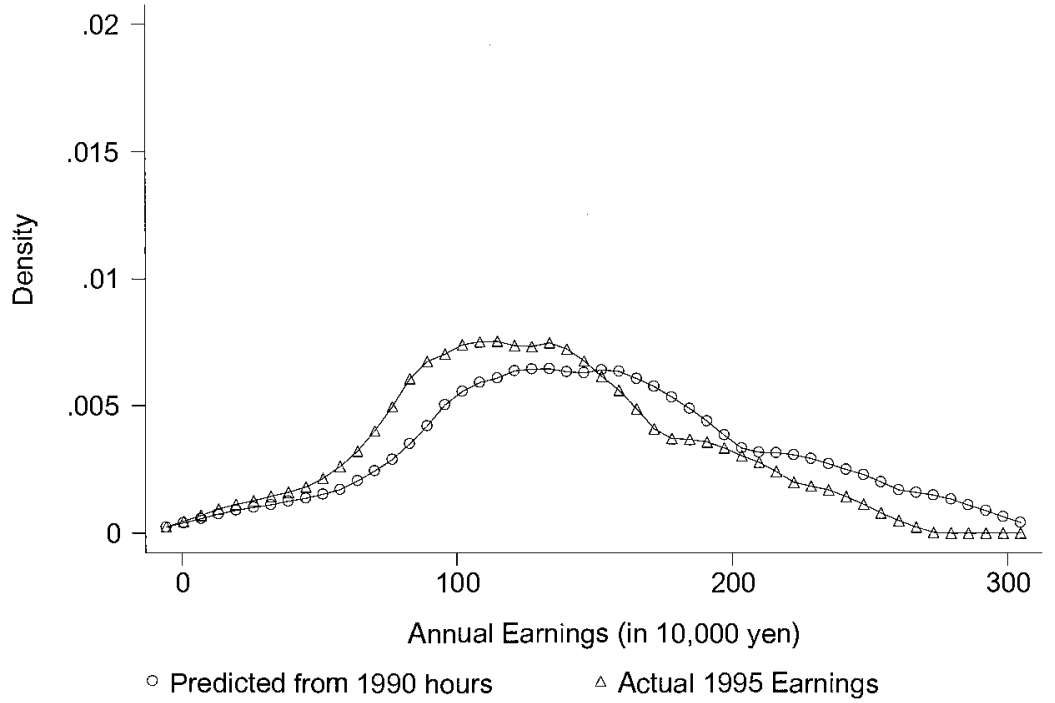

Fig. 12.4 Earnings distribution for single women

Source: Author's calculations from the GSPWC data. 
Distribution of Hours and Earnings by Marital Status, 1990 and 1995 (\%)

\begin{tabular}{|c|c|c|c|c|c|c|c|c|}
\hline \multirow[b]{2}{*}{$\begin{array}{l}\text { Cell } \\
\text { Number }\end{array}$} & \multicolumn{4}{|c|}{1990} & \multicolumn{4}{|c|}{1995} \\
\hline & $\begin{array}{l}\text { Weekly } \\
\text { Hours }\end{array}$ & $\begin{array}{c}\text { Annual } \\
\text { Earnings }\end{array}$ & Married & Single & $\begin{array}{l}\text { Weekly } \\
\text { Hours }\end{array}$ & $\begin{array}{c}\text { Annual } \\
\text { Earnings }\end{array}$ & Married & Single \\
\hline 1 & $<22$ & $<90$ & 12.84 & 5.26 & $<20$ & $<90$ & 9.02 & 5.58 \\
\hline 2 & $<22$ & $90-110$ & 2.78 & 1.28 & $<20$ & $90-130$ & 2.95 & 0.67 \\
\hline 3 & $<22$ & $110+$ & 0.56 & 2.44 & $<20$ & $130+$ & 0.55 & 1.41 \\
\hline 4 & $22-33$ & $<90$ & 21.47 & 10.67 & $20-30$ & $<90$ & 17.26 & 6.79 \\
\hline 5 & $22-33$ & $90-110$ & 11.75 & 5.28 & $20-30$ & $90-130$ & 19.17 & 6.13 \\
\hline 6 & $22-33$ & $110+$ & 5.70 & 7.06 & $20-30$ & $130+$ & 1.97 & 3.98 \\
\hline 7 & $33+$ & $<90$ & 12.06 & 9.16 & $30+$ & $<90$ & 8.95 & 8.24 \\
\hline 8 & $33+$ & $90-110$ & 10.13 & 10.45 & $30+$ & $90-130$ & 19.47 & 18.74 \\
\hline 9 & $33+$ & $110+$ & 22.72 & 48.39 & $30+$ & $130+$ & 20.64 & 48.46 \\
\hline
\end{tabular}

Source: Author's calculations from the Ministry of Labor $(1992,1997)$.

Notes: The sample is restricted to female part-time workers aged twenty-five to fifty-four. Annual earnings are measured in 10,000 yen.

time workers work relatively long hours. In 1995, only 13 percent of married female part-time workers worked less than twenty hours per week, whereas 49 percent worked thirty hours or more.

From 1990 to 1995 there were large changes in the distribution of workers over the nine cells, especially for married women. The share earning less than 0.9 million yen per year declined for both married and single women. Due to the increase in hourly wages, it became easier to earn higher income. However, many married part-time workers wanted to constrain their earnings to be less than 1 million yen per year, so the share earning more than 1 million yen remained constant. The changes in the share of workers in each cell in table 12.3 are further complicated by changes in threshold hours. The reduction in the hours threshold acts to increase the share of workers satisfying the conditions for participation. The tendency to constrain labor supply works in the opposite direction, increasing the share of workers who need not enroll.

\subsection{Results}

\subsubsection{The Degree of Noncompliance}

Conditional on meeting the participation criteria, noncompliance may be more common among married women than single women. ${ }^{24}$

24. Most of the analysis in this paper is concerned with enrollment in social insurance conditional on labor supply choices. If enrollment behavior were uniform conditional on hours and earnings only, labor supply decisions would basically determine social insurance participation, so there would be no reason to analyze participation conditional on earnings and 
Table 12.4 presents 1990 and 1995 participation shares for each of the nine hours-earnings categories. The table lists the results separately by marital status, as labor supply and participation behavior differ between these two groups. Social insurance participation is clearly related to earnings and hours. The share of married women who did not participate in any of the social insurance programs in 1990 is over 97 percent in cell one (weekly hours less than twenty-two and earnings of less than 0.9 million yen), while the same share for cell nine (weekly hours of more than thirty-three and earnings of more than 1.1 million yen) is 10.7 percent. A similar pattern is observed in other groups. So, although noncompliance may exist to some extent, it is not as widespread as some previous research suggests.

In all four samples, almost 80 percent of workers in cell nine participate in all three programs (EP, health insurance, and EI). In this group, married women are no less likely to participate than single women: The option for married women to receive benefits from their husbands' coverage does not seem to affect participation in this range.

For cells seven and eight, nonparticipation is significantly higher for married women than for single women. In 1995, 46 percent of married workers in cell eight did not enroll in any of the insurance programs, compared to 22 percent of single workers. The proportion of workers in cell eight who participated in all of the insurance programs is 31 percent for married women and 52 percent for single women. The larger drop in participation in EP and health insurance from cell nine to cell eight for married women than for single women suggests that "worker-side conditions" significantly affect participation by married women.

Those in cell eight satisfy the conditions for EI participation, yet only 48 percent of married women participated in EI in 1995, whereas 69 percent of single women did. Participation in EI therefore seems to be affected by marital status. Thus, conditional on being in cell eight, EI participation is also correlated with participation in EP and health insurance. In any case, EI participation is not very high among those who satisfy the conditions for EI only (cell five) - for married women, it was 30 percent in 1990 and 43 percent in 1995. Even though EI is mandated for a wider class of parttime workers than are EP and health insurance, EI coverage may not be fully enforced.

hours. As the following analysis shows, however, social insurance participation seems to be affected by variables like marital status, age, and firm size, conditional on hours and earnings. The husband's employer may check the income of dependent family members carefully to identify whether they qualify as dependents. If this happens, married women who meet the criteria are not less likely to participate by themselves than are single women, since the benefit for the wife is denied by the husband's employer. 


\begin{tabular}{|c|c|c|c|c|c|c|c|}
\hline $\begin{array}{l}\text { Cell } \\
\text { Number }\end{array}$ & $\begin{array}{l}\text { Weekly } \\
\text { Hours }\end{array}$ & $\begin{array}{c}\text { Annual } \\
\text { Earnings } \\
(10,000 \text { yen })\end{array}$ & $\begin{array}{c}\text { No } \\
\text { Insurance } \\
(\%)\end{array}$ & $\begin{array}{c}\text { EI } \\
\text { Only } \\
(\%)\end{array}$ & $\begin{array}{c}\text { EPH } \\
\text { Only } \\
(\%)\end{array}$ & $\begin{array}{c}\text { All } \\
\text { Insurance } \\
(\%)\end{array}$ & $\begin{array}{c}\text { Sample } \\
\text { Size }\end{array}$ \\
\hline \multicolumn{8}{|c|}{ 1990, Married } \\
\hline 1 & $<22$ & $<90$ & 97.52 & 1.58 & 0.30 & 0.60 & 1,276 \\
\hline 2 & $<22$ & $90-110$ & 92.57 & 3.39 & 1.74 & 2.30 & 286 \\
\hline 3 & $<22$ & $110+$ & 76.25 & 0.65 & 4.43 & 18.68 & 77 \\
\hline 4 & $22-33$ & $<90$ & 86.65 & 7.65 & 0.91 & 4.78 & 2,418 \\
\hline 5 & $22-33$ & $90-110$ & 69.15 & 15.22 & 0.90 & 14.73 & 1,573 \\
\hline 6 & $22-33$ & $110+$ & 28.33 & 5.30 & 1.06 & 64.81 & 870 \\
\hline 7 & $33+$ & $<90$ & 71.21 & 8.83 & 1.10 & 18.87 & 1,270 \\
\hline 8 & $33+$ & $90-110$ & 57.21 & 9.46 & 2.34 & 30.99 & 1,159 \\
\hline 9 & $33+$ & $110+$ & 10.72 & 3.12 & 2.71 & 83.45 & 4,254 \\
\hline \multicolumn{8}{|c|}{ 1990, Single } \\
\hline 1 & $<22$ & $<90$ & 93.23 & 5.09 & 0.00 & 1.68 & 71 \\
\hline 2 & $<22$ & $90-110$ & 98.97 & 1.03 & 0.00 & 0.00 & 13 \\
\hline 3 & $<22$ & $110+$ & 87.59 & 0.00 & 2.61 & 9.80 & 37 \\
\hline 4 & $22-33$ & $<90$ & 72.48 & 8.27 & 7.13 & 12.12 & 145 \\
\hline 5 & $22-33$ & $90-110$ & 54.32 & 14.83 & 6.40 & 24.45 & 91 \\
\hline 6 & $22-33$ & $110+$ & 41.61 & 2.63 & 2.33 & 53.44 & 139 \\
\hline 7 & $33+$ & $<90$ & 33.37 & 4.31 & 3.29 & 59.03 & 174 \\
\hline 8 & $33+$ & $90-110$ & 24.76 & 9.38 & 6.10 & 59.76 & 179 \\
\hline 9 & $33+$ & $110+$ & 13.40 & 4.65 & 2.28 & 79.67 & 1,153 \\
\hline \multicolumn{8}{|c|}{ 1995, Married } \\
\hline 1 & $<20$ & $<90$ & 83.41 & 1.41 & 13.68 & 1.50 & 632 \\
\hline 2 & $<20$ & $90-130$ & 80.69 & 7.75 & 9.23 & 2.33 & 269 \\
\hline 3 & $<20$ & $130+$ & 17.00 & 21.16 & 23.90 & 37.95 & 47 \\
\hline 4 & $20-30$ & $<90$ & 78.59 & 11.57 & 5.46 & 4.38 & 1,065 \\
\hline 5 & $20-30$ & $90-130$ & 51.25 & 30.31 & 5.56 & 12.88 & 1,533 \\
\hline 6 & $20-30$ & $130+$ & 14.08 & 8.77 & 7.53 & 69.62 & 204 \\
\hline 7 & $30+$ & $<90$ & 52.74 & 18.87 & 11.29 & 17.10 & 662 \\
\hline 8 & $30+$ & $90-130$ & 46.05 & 16.67 & 6.01 & 31.26 & 1,646 \\
\hline 9 & $30+$ & $130+$ & 6.83 & 2.98 & 4.42 & 85.77 & 2,379 \\
\hline \multicolumn{8}{|c|}{ 1995, Single } \\
\hline 1 & $<20$ & $<90$ & 57.87 & 0.00 & 21.43 & 20.70 & 56 \\
\hline 2 & $<20$ & $90-130$ & 84.87 & 6.77 & 8.36 & 0.00 & 17 \\
\hline 3 & $<20$ & $130+$ & 55.15 & 0.00 & 40.78 & 4.06 & 26 \\
\hline 4 & $20-30$ & $<90$ & 77.28 & 4.59 & 11.36 & 6.76 & 75 \\
\hline 5 & $20-30$ & $90-130$ & 67.47 & 5.58 & 11.59 & 15.36 & 66 \\
\hline 6 & $20-30$ & $130+$ & 18.57 & 3.37 & 21.68 & 56.38 & 44 \\
\hline 7 & $30+$ & $<90$ & 44.34 & 9.65 & 3.89 & 42.12 & 119 \\
\hline 8 & $30+$ & 90-130 & 22.10 & 16.96 & 8.96 & 51.97 & 259 \\
\hline 9 & $30+$ & $130+$ & 8.55 & 6.21 & 2.84 & 82.39 & 881 \\
\hline
\end{tabular}

Source: Author's calculations from the GSPWC data

Notes: All Insurance $=$ enrollment in EP, health insurance and employment insurance. EI Only = enrollment in employment insurance only. EPH Only = enrollment in EP and health insurance, but not in employment insurance. No Insurance $=$ enrollment in none of the three. For workers under sixty-five, conditions for enrollment are the same for EP and health insurance. 


\subsubsection{Decomposition of the Enrollment Difference into Labor Supply Effects and Enrollment Effects}

In this section, differences in enrollment patterns of various groups are decomposed into several factors. The first comparison is that of married women and single women. This comparison is important because the low participation rates of part-time workers are partly caused by provisions in the social insurance system that allow married women to receive benefits through their husbands' coverage. Single women do not have such an opportunity, so comparing the two groups reveals the effects of the option to receive benefits from a husband's insurance..$^{25} \mathrm{I}$ decompose the differences into a labor supply effect and an enrollment behavior effect. The former is the difference in enrollment due to labor supply choices (hours and earnings), and the latter is the difference in likelihood of enrollment conditional on hours and earnings. ${ }^{26}$

The second comparison is that of 1990 and 1995 participation rates. Overall, enrollment in social insurance by part-time workers increased between the two years. As the bottom panel of table 12.2 shows, the proportion who did not participate in any of the three social insurance programs declined 12 percent for married women and 7 percent for single women. These overall changes are decomposed into a labor supply effect, an enrollment behavior effect, and a rule effect. This last one captures the effect of the threshold revisions for hours and earnings that took place between 1990 and 1995.

The decompositions are done in the following manner. ${ }^{27}$ Let $L$ be the fraction of workers by labor force status in each of the categories defined by the hours-earnings pairs. The hours-earnings pairs are defined by the thresholds for participation in EP, health insurance, and EI in each year (see table 12.1). Denote $L_{1}$ as the distribution of labor force status of the group of interest (for example, married women) and $L_{0}$ as the distribution

25. Health insurance (but not pension) coverage can be obtained from another insured and employed family member (for example, from parents). Some single women may have health insurance coverage in this way. However, in 1990, 57 percent of the single women in the sample were divorced or widowed. They are probably less likely to receive health insurance from their parents. The categories of "never married" or "divorced or widowed" were only included in the 1990 survey.

26. Terming the former a labor supply effect may be a bit misleading because it refers here to how the probability distribution over the nine cells changed between the two years. The likelihood of a worker's being included in each of the cells depends on both hourly wages and weekly hours.

27. It is possible to perform similar decompositions by using regression coefficients obtained from a model that predicts participation in the two insurance groups (EP and health insurance, and EI). However, such decompositions are quite sensitive to the estimated coefficients. Unless the estimated parameters predict the outcomes well (here, outcome refers to the probabilities of the four states that correspond to participation in the two insurance groups), such decompositions may not be reliable. For this reason, the decomposition here is based on simple accounting, which does not use a behavioral model. 
of labor force status of the comparison group (for example, single women). Using $i$ to index labor supply categories, $L_{i 1}$ in this case represents the fraction of married workers whose labor supply decisions place them in category $i$. Let $p_{j k}$ be the probability distribution over the four participation states (indexed by $j$ ) by workers in the group $k(k=0,1)$. The participation states correspond to (a) not enrolled in employer-provided health insurance nor EP nor EI; (b) enrolled in EI only; (c) enrolled in employerprovided health insurance and EP only; and (d) enrolled in all three. Let $\beta_{i j k}$ be the probability distribution over the four participation states for those in the $k$ th group and the $i$ th labor supply status category. Then, the difference in the probability of being in participation state $j$ between the two groups can be written as

$$
p_{j 1}-p_{j 0}=\sum_{i} \beta_{i j 1} L_{i 1}-\sum_{i} \beta_{i j 0} L_{i 0}=\sum_{i}\left(\beta_{i j 1}-\beta_{i j 0}\right) L_{i 1}+\sum_{i} \beta_{i j 0}\left(L_{i 1}-L_{i 0}\right)
$$

This formula is used to compare the participation patterns of married women to single women.

In comparing participation in 1990 and 1995, it is necessary to control for the changes in the participation conditions that occurred. As explained in section 12.2, the weekly hours thresholds for participation were reduced between 1990 and 1995. For EP and health insurance, the threshold was cut from thirty-three hours per week to thirty hours per week; for EI, it was cut from twenty-two hours per week to twenty hours per week. On the other hand, the earnings threshold for EP and health insurance increased from 1.1 million yen to 1.3 million yen; the threshold for EI remained at 0.9 million yen. These factors will change the likelihood of participation even if hours and earnings are kept constant. To account for this, I decompose the second term of equation (1) into a term that controls for the changes in the rules and a term that captures the changes in labor supply distributions. Specifically, let $\tilde{L}_{i 0}$ be the probability distribution over the nine categories of labor supply choices if the 1995 rules were applied to 1990 hours and earnings. Then $\sum_{i} \beta_{i j 0}\left(\tilde{L}_{i 0}-L_{i 0}\right)$ corresponds to the changes in participation due to the changes in the rule, evaluated at the participation propensity of group $0\left(\beta_{i j 0}\right)$. Therefore, in comparing 1990 and 1995 outcomes, the decomposition becomes

$$
p_{j 1}-p_{j 0}=\sum_{i} \beta_{i j 0}\left(\tilde{L}_{i 0}-L_{i 0}\right)+\sum_{i} \beta_{i j 0}\left(L_{i 1}-\tilde{L}_{i 0}\right)+\sum_{i}\left(\beta_{i j 1}-\beta_{i j 0}\right) L_{i 1} .
$$

Here, the subscript 1 corresponds to the 1995 outcome, and 0 to the 1990 outcome. The first term is the change in rule term, the second term is the labor supply term, and the final term is the change in participation behavior term.

The results of this decomposition are shown in table 12.5. The changes in rules have mixed effects on participation: The fall in the hours threshold and the rise in the income threshold moved the distribution over the nine 
Table 12.5

Decomposition of Differences in Participation Behavior

\begin{tabular}{|c|c|c|c|c|}
\hline & $\begin{array}{c}\text { No Insurance } \\
(\%)\end{array}$ & $\begin{array}{c}\text { EI Only } \\
(\%)\end{array}$ & $\begin{array}{l}\text { EPH Only } \\
\quad(\%)\end{array}$ & $\begin{array}{c}\text { All Insurance } \\
(\%)\end{array}$ \\
\hline \multicolumn{5}{|c|}{ A. Comparison of Married and Single Women, 1995} \\
\hline Married & 48.78 & 14.00 & 6.89 & 30.33 \\
\hline Single & 26.63 & 7.82 & 7.55 & 58.00 \\
\hline Difference & 22.15 & 6.18 & -0.66 & -27.67 \\
\hline \multicolumn{5}{|l|}{ Decomposition } \\
\hline Difference in labor supply & 18.11 & -0.24 & 2.15 & -20.01 \\
\hline $\begin{array}{l}\text { Difference in participation } \\
\text { behavior }\end{array}$ & 4.03 & 6.45 & -2.80 & -7.68 \\
\hline \multicolumn{5}{|c|}{ B. Comparison of Married Women, 1990 and 1995} \\
\hline Actual 1995 & 48.78 & 14.00 & 6.89 & 30.33 \\
\hline Actual 1990 & 60.70 & 6.76 & 1.46 & 31.07 \\
\hline Difference & -11.92 & 7.24 & 5.43 & -0.74 \\
\hline \multicolumn{5}{|l|}{ Decomposition } \\
\hline $\begin{array}{l}\text { Difference due to enrollmen } \\
\text { conditions }\end{array}$ & -0.07 & 0.59 & 0.16 & -0.67 \\
\hline Difference in labor supply & -0.16 & 0.52 & -0.06 & -0.33 \\
\hline \multicolumn{5}{|l|}{ Difference in participation } \\
\hline \multicolumn{5}{|c|}{ C. Comparison of Single Women, 1990 and 1995} \\
\hline Actual 1995 & 26.63 & 7.82 & 7.55 & 58.00 \\
\hline Actual 1990 & 33.98 & 5.76 & 3.37 & 56.89 \\
\hline Difference & -7.35 & 2.06 & 4.18 & 1.11 \\
\hline \multicolumn{5}{|l|}{ Decomposition } \\
\hline $\begin{array}{l}\text { Difference due to enrollmen } \\
\text { conditions }\end{array}$ & -3.33 & 0.60 & 0.51 & 2.24 \\
\hline Difference in labor supply & 0.24 & -0.12 & -0.36 & 0.23 \\
\hline $\begin{array}{l}\text { Difference in participation } \\
\text { behavior }\end{array}$ & -4.25 & 1.58 & 4.02 & -1.36 \\
\hline
\end{tabular}

Source: Author's calculations from the GSPWC data

Note: All Insurance $=$ enrollment in EP, health insurance, and employment insurance. EI Only = enrollment in employment insurance only. EPH Only = enrollment in EP and health insurance, but not in employment insurance. No Insurance $=$ enrollment in none of the three. For workers under sixty-five, conditions for enrollment are the same for EP and health insurance.

cells in opposite directions. On the one hand, the reduction in the hours threshold made the fraction of workers who exceeded this threshold go up; on the other hand, the rise in the earnings threshold for EP and health insurance made the fraction of workers in cell nine (who satisfy conditions for participating in all three programs) fall. The upward adjustment of the EP and health insurance threshold is comparable to the rate of general wage increase, so if labor supply decisions had remained the same, the decline in the fraction of workers who meet all the conditions for participation would not have occurred. However, as shown in table 12.3 and figures 
12.1 and 12.2, part-time workers generally reduced their work hours during this period, so their earnings growth was limited. Therefore, the fractions in cell five (twenty to thirty hours per week and annual earnings of $0.9-1.3$ million yen) and cell eight (over thirty hours per week and annual earnings of $0.9-1.3$ million yen) rose. Workers in cell five are not required to participate in EP and health insurance, since hours are less than the threshold. Married women in cell eight are eligible for benefits through their husbands' coverage.

Table 12.5, panel A shows the results of a comparison of married and single women in 1995. Overall, married women are 22 percent more likely to participate in none of the insurance programs, 6 percent more likely to participate in EI only, and 28 percent less likely to participate in all of the programs. A significant portion of each of these differences is explained by the labor supply term. The labor supply factor predicts that married women are 18 percent more likely to participate in none of the programs and 20 percent less likely to participate in all of the programs. Married and single women differ in participation behavior as well. Married women are 4 percent more likely to participate in none of the programs and 8 percent less likely to participate in all of them. Table 12.5 , panels B and C, show the 1990 to 1995 comparison separately by marital status. Overall, the fraction participating in none of the programs fell, and the fraction participating in EI only and in EP and health insurance only went up. For single women, the fraction participating in EP and health insurance increased only somewhat. For both groups, the fraction participating in all three programs remained unchanged. The changes in distribution from 1990 to 1995 are largely explained by changes in participation propensity. ${ }^{28}$

\subsection{Social Insurance Participation Behavior at the Individual Level}

\subsubsection{Base Results}

In this section, I examine participation behavior at the individual level. Specifically, I look at whether individual participation patterns follow the predictions made in section 12.2.3. I present probit models that predict participation. The dependent variable is either a dummy variable that equals 1 if the worker participates in EP and health insurance and zero otherwise, or a similar dummy for participation in EI. Explanatory variables include dummies for marital status, age category, and firm size, as well as years of tenure and other available controls. If married women are less likely to participate in EP and health insurance, the coefficient of the married dummy will be negative. If older workers are less likely to participate,

28. Some of the decomposition results are affected by the order of decomposition, but the general pattern is basically similar. 
the coefficients of the older age category dummies will be negative. If large firms are more likely to comply with the rules or if they tend to provide higher benefits, the coefficients of the large firm dummies will be positive.

The four panels of table 12.6 show the regression results from the univariate probit models. Table 12.6, panels A and B, contains results for participation in EP and health insurance, and table 12.6, panels $C$ and $\mathrm{D}$, presents results for EI. Separate regressions are estimated for the sample of workers who meet the conditions for mandatory participation and for the sample of workers who do not. ${ }^{29}$ Since participation patterns differ across industries, regressions are also run separately by industry (summary statistics on participation by industry can be found in table 12A.1 in the appendix).

Table 12.6, panel A, lists the estimates from the sample of workers who meet the conditions for mandatory participation in EP and health insurance. Among this sample of workers, neither marital status nor age affects participation. The point estimate of the married dummy is positive, so conditional on satisfying participation conditions, married women are no less likely to participate in EP and health insurance. The coefficients of the age dummies are insignificant, so older workers are no less likely to participate. Participation is higher in larger firms. The coefficients on the 1995 year dummy suggest that the probability of participation increased by 6 percent in the service industry and by 8 percent in wholesale and retail industries. In manufacturing, the coefficient on the 1995 year dummy is small and statistically insignificant. In 1995, the yen appreciated against the dollar significantly, which might have reduced labor demand in manufacturing. Since shorter work hours would reduce the likelihood of participation, participation may not have risen in manufacturing despite the general trend toward increasing participation.

Table 12.6, panel B, shows the estimates from the sample of individuals who do not meet all of the conditions for mandatory enrollment in EP and health insurance. As shown in table 12.4, even though participation is not required, some workers do participate. Participation in this group also increased from 1990 to 1995, especially in the service sector. Here, married women are less likely to participate than single women. Older workers are also less likely to participate, suggesting that the higher costs of paying EP and health care benefits to older workers may forestall participation. ${ }^{30}$

Table 12.6, panel C, shows the univariate probit results for EI for work-

29. Regressions presented here are not based on a complete model of labor supply and social insurance participation. A complete framework would model the hours, participation in EP and health insurance, and participation in EI decisions simultaneously. Such an analysis is beyond the scope of the paper.

30. I also estimated a similar specification using a subsample of workers in cells seven and eight. Workers in this sample satisfied the employer-side conditions, but not the worker-side conditions. The tendency for older workers to be less likely to participate is stronger in this subsample. 


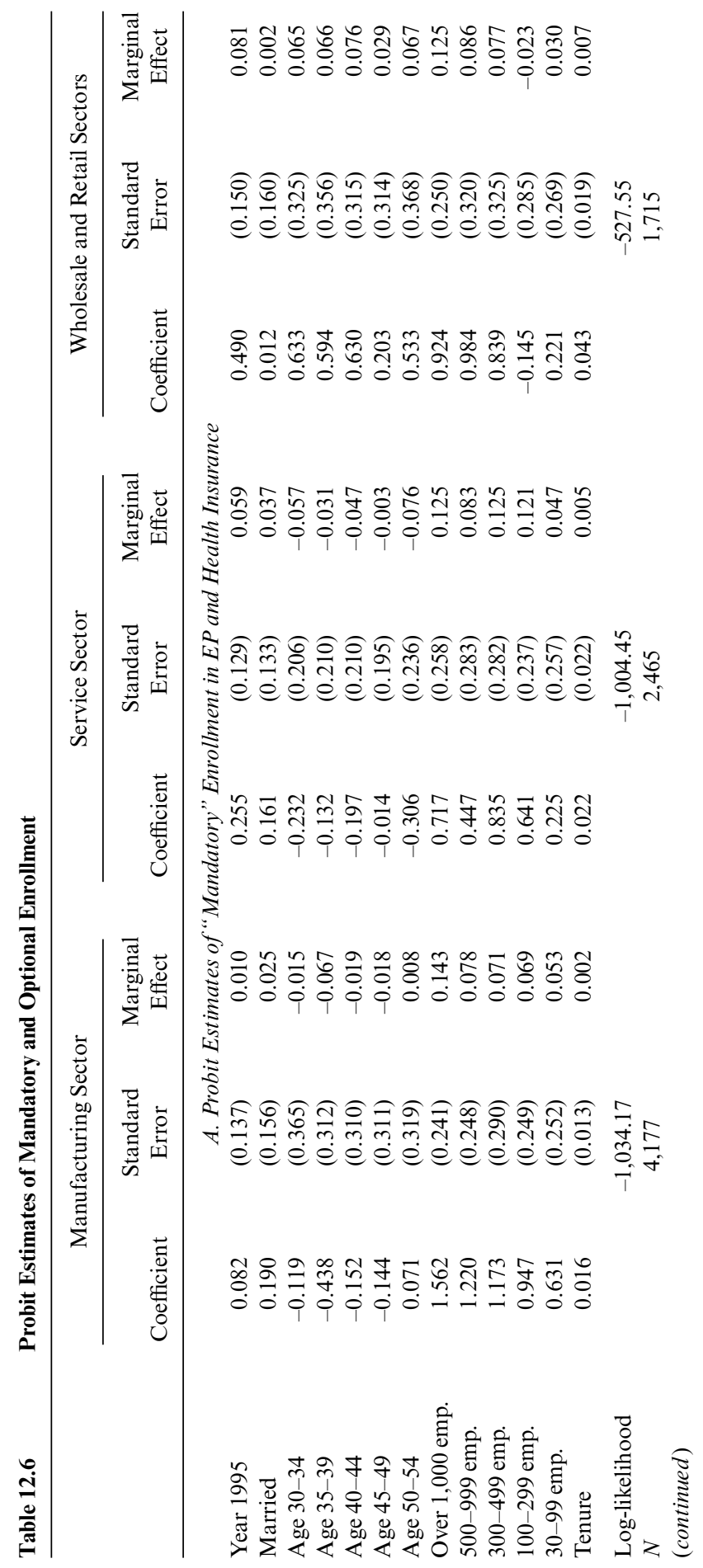




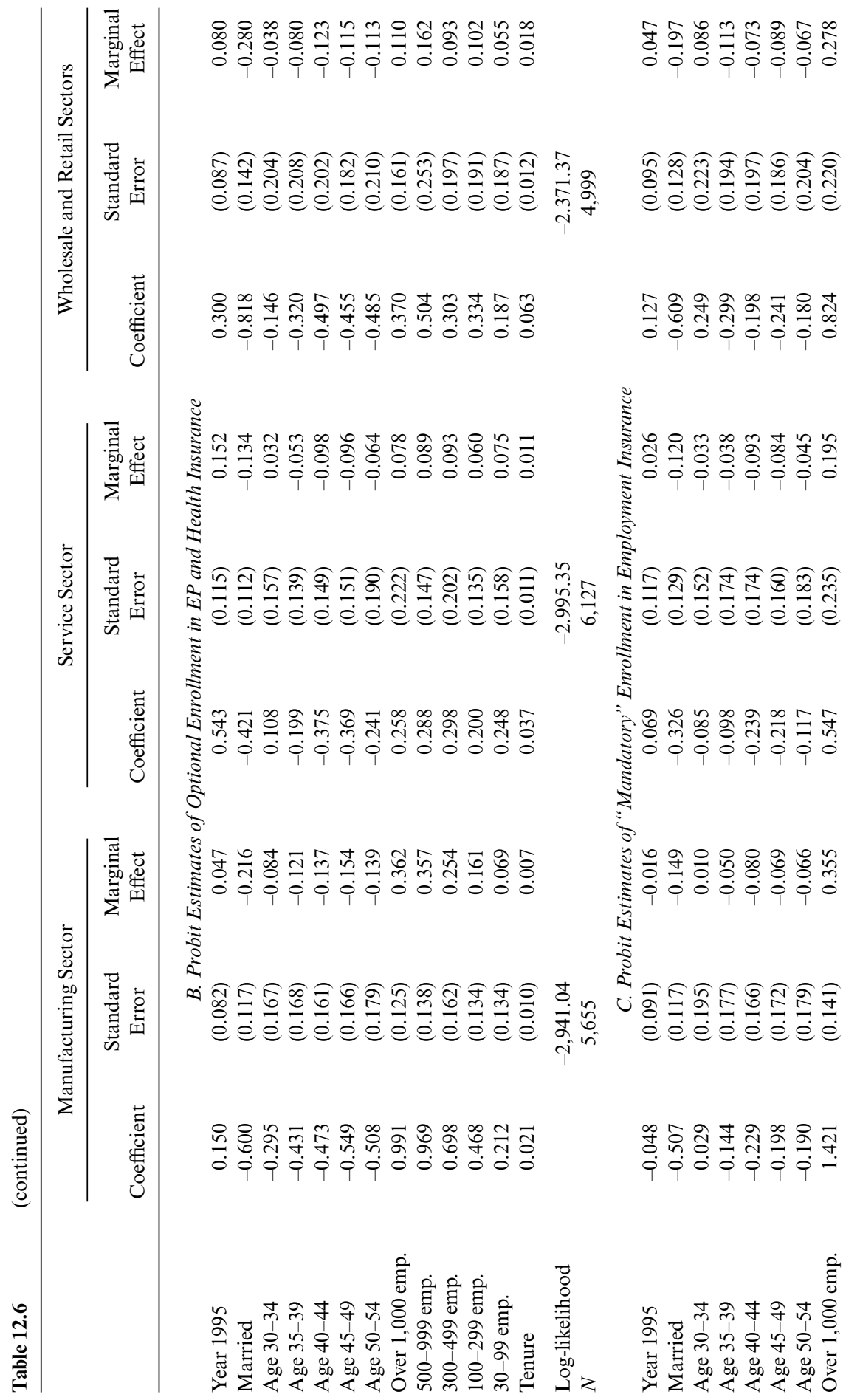




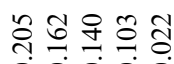

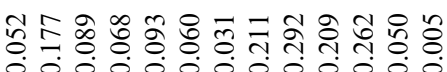

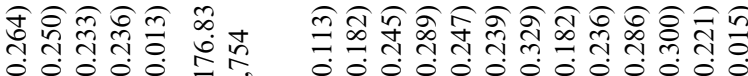
eงese

象员국영

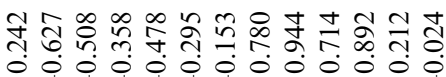

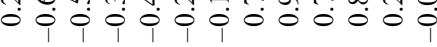

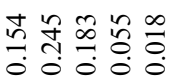

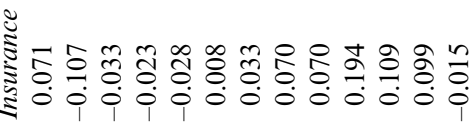

ฐ

害

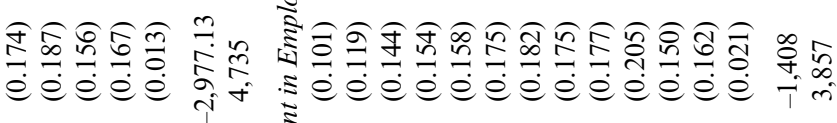
害

중도응

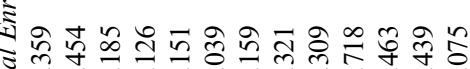

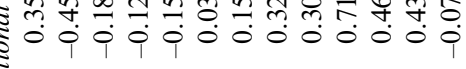
ป

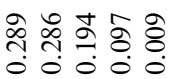

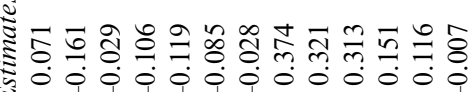

:

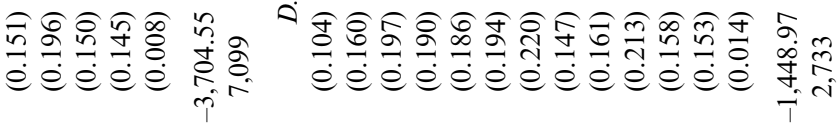

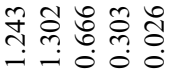

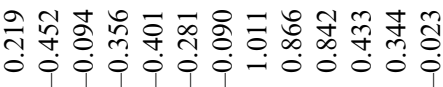

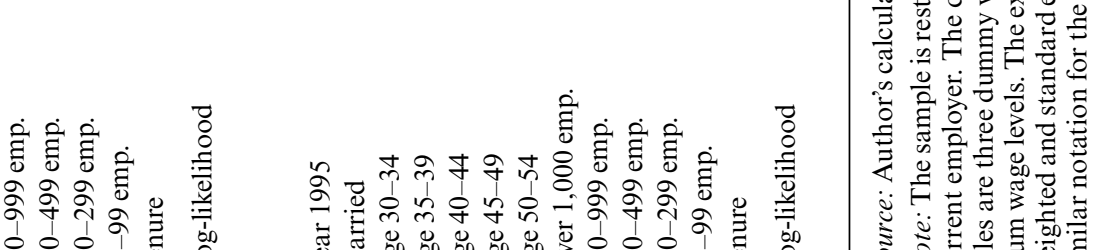

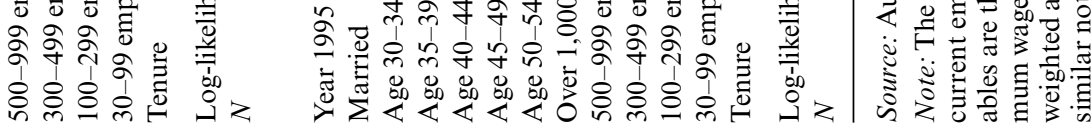


ers who meet the participation criteria. Unlike the case of EP and health insurance, married women are less likely to participate than single women. As noted in the discussion of summary statistics in section 12.3.1, some married part-time workers who meet the conditions for EI but not those for EP and health insurance do not participate in EI, which may affect the results. This possibility is investigated further below. Most of the age dummy coefficients are insignificant. This is consistent with the hypothesis that, since EI costs are not higher for older workers, older workers are no less likely to participate in EI than younger workers. Again, participation is higher in larger firms.

Table 12.6, panel D, lists results for EI for workers who do not meet the participation conditions. In this specification, married women are less likely to participate and age is not significantly related to lower participation. These patterns are similar to those in table 12.6, panel C.

\subsubsection{Correlation between EI Participation and EP and Health Insurance Participation}

The results from the EI univariate probit model suggest that participation in EI is influenced by participation in EP and health insurance. To incorporate this effect into the regression models, I estimate a univariate probit model that uses the sample of workers who meet the conditions for EI but do not belong to cell nine. These workers are much less likely to participate in EP and health insurance. The results are shown in table 12.7. For this group, the characteristics that discourage participation in health insurance and EP (marital status or age) generally seem to discourage participation in EI. ${ }^{31}$ For example, although participation in EI is considered to be unrelated to marital status, the coefficient of the married dummy in the wholesale and retail sample in table 12.7 is significantly negative. Furthermore, although EI participation is unlikely to be related to age, the marginal effect of older age dummies in manufacturing is significantly negative. So, even though EI has provisions for short-hour workers that allow more part-time workers to participate, participation in EI is affected by factors that are related to participation in EP and health insurance.

\subsubsection{Additional Evidence on Participation in Employment Insurance}

In section 12.4.2, I showed that the rise in social insurance participation from 1990 to 1995 is largely due to an increase in participation propensity. There are two possible reasons for the increase in participation. One is stricter enforcement of the participation rules. In particular, the shorthour provision of EI that mandates enrollment by workers with twenty-

31. I also estimated an unweighted bivariate probit model for the sample of workers in cell eight. These workers satisfy the conditions for EI participation, but not the worker-side conditions for EP and health insurance enrollment. The model suggests that the error terms in the two equations are highly correlated. 


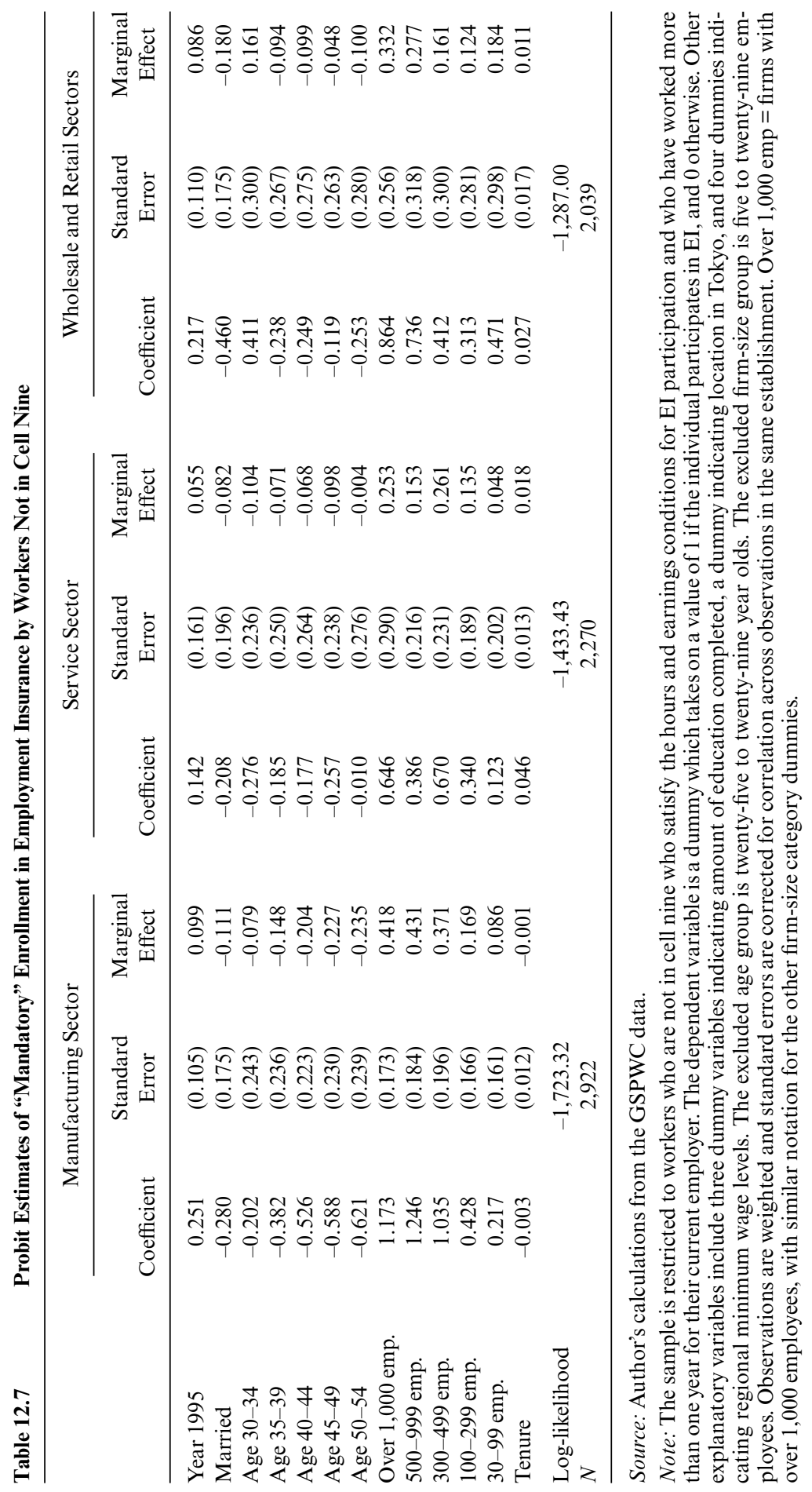


two to thirty-two hours or more than 0.9 million yen in earnings was introduced in April of 1989 (the criterion was later changed to twenty to twenty-nine hours per week). As the following data show, enrollment in this category of EI grew rapidly in the 1990s. As the new system became better known among firms and workers, participation in EI may have increased. The second reason is an increased desire to enroll in EP (and health insurance) by single part-time employees. Starting in 1991, those aged twenty and above were required to participate in the public pension program regardless of their earnings. Therefore, a single person without an employer-provided public pension has to enroll in the national pension program and pay a premium of about 13,300 yen per month (1999 premium amount). Before that, participation was voluntary for nonworking or low-income individuals. This change might have made enrollment in EP and health insurance at the employer level a more attractive option for single part-time workers, which might have increased enrollment, leading to higher enrollment in the EP and Health Insurance Only category. Married persons whose spouses enroll in an EP program can be covered without an additional premium (see section 12.2.1).

Here, I present additional evidence on the increase in participation in EI. I use aggregate enrollment data from EI administrative records. Table 12.8 shows the number of women who participated in EI by type of worker (short-hour or regular) and age group. EI for short-hour workers was applied to those who worked twenty-two to thirty-two hours per week in 1992 and twenty to twenty-nine hours per week in 1997. Employment insurance for regular workers was applied to those who worked over thirty-three hours per week in 1992 and over thirty hours per week in 1997. The first two columns show that, from 1992 to 1997, the enrollment of short-hour workers more than doubled for those aged forty-five or over. The next two columns show the ratio of enrollment to the number of workers who work twenty-two to thirty-four hours per week, to control for the possibility that the raw increase in enrollment was caused by an increase in the number of workers. ${ }^{32}$ Even controlling for the overall increase in part-time work, enrollment of short-hour workers rose significantly, especially among older workers. This is consistent with the rise in participation in EI only shown in table 12.5. For comparison, changes in the enrollment of regular workers are shown as well (note that part-time workers who work more than thirty hours enroll as regular workers). Since the data do not have infor-

32. For our purposes, it is desirable to use the number of workers whose weekly hours are between the thresholds (twenty to twenty-nine hours per week in 1997). However, such numbers are not published in the nationally representative data set. Not many Japanese governmental surveys ask employment status and weekly working hours in the same survey questionnaire. One such survey is the Special Survey of the Labor Force Survey, but the published data do not contain figures for the number of workers who work twenty to twenty-nine hours per week. 
Employment Insurance Participation, 1992 and 1997

\begin{tabular}{|c|c|c|c|c|}
\hline \multirow[b]{2}{*}{ Age } & \multicolumn{2}{|c|}{$\begin{array}{l}\text { Raw Enrollment } \\
\text { (thousands) }\end{array}$} & \multicolumn{2}{|c|}{$\begin{array}{c}\text { Ratio of Enrollment } \\
\text { to the Number of } \\
\text { workers }\end{array}$} \\
\hline & 1992 & 1997 & 1992 & 1997 \\
\hline \multicolumn{5}{|c|}{ Employment Insurance Participation by Short-hour Workers, 1992 and 1997} \\
\hline$<20$ & 1.77 & 3.17 & 0.032 & 0.053 \\
\hline $20-24$ & 11.97 & 20.64 & 0.082 & 0.092 \\
\hline $25-29$ & 21.73 & 33.61 & 0.112 & 0.143 \\
\hline $30-34$ & 24.21 & 41.64 & 0.105 & 0.150 \\
\hline $35-39$ & 39.42 & 66.58 & 0.107 & 0.175 \\
\hline $40-44$ & 73.08 & 101.71 & 0.126 & 0.208 \\
\hline $45-49$ & 59.95 & 143.17 & 0.128 & 0.227 \\
\hline $50-54$ & 42.00 & 94.47 & 0.124 & 0.232 \\
\hline $55-59$ & 23.41 & 59.49 & 0.112 & 0.197 \\
\hline $60-64$ & 13.29 & 31.29 & 0.113 & 0.184 \\
\hline \multicolumn{5}{|c|}{ Employment Insurance Participation by Regular-hour Workers, 1992 and 1997} \\
\hline$<20$ & $450.04^{1}$ & 223.64 & 0.872 & 0.793 \\
\hline $20-24$ & 2515.78 & 2191.34 & 0.862 & 0.836 \\
\hline $25-29$ & 1566.04 & 1955.48 & 0.804 & 0.840 \\
\hline $30-34$ & 834.05 & 1061.05 & 0.707 & 0.798 \\
\hline $35-39$ & 817.02 & 861.52 & 0.648 & 0.736 \\
\hline $40-44$ & 1256.42 & 984.72 & 0.698 & 0.721 \\
\hline $45-49$ & 1111.16 & 1399.15 & 0.718 & 0.749 \\
\hline $50-54$ & 1047.28 & 1098.75 & 0.764 & 0.778 \\
\hline $55-59$ & 768.00 & 908.48 & 0.778 & 0.810 \\
\hline $60-64$ & 320.29 & 387.67 & 0.725 & 0.814 \\
\hline
\end{tabular}

Source: Enrollment data are from the Annual Report on Employment Insurance (various years). Number of workers working twenty-two to thirty-four hours per week are based on the published data from the Statistical Bureau (1984 and 1998).

Notes: Short-hour workers are defined as working twenty-two to thirty-two hours per week in 1992 and twenty to twenty-nine hours per week in 1997. Regular-hour workers are defined as working at least thirty-three hours per week in 1992 and at least thirty hours per week in 1997. Number of workers (in the denominator) is defined as those working at least thirty-five hours per week. Many public-sector employees who are not covered by EI are counted in the denominator. Therefore, the ratio is not the enrollment rate.

mation on EP and health insurance participation or marital status, it is impossible to assess the effect of the system on participation in detail. Nonetheless, the figures suggest that one of the reasons for higher participation in later years is stricter enforcement of the new rules.

\subsection{Conclusion}

In this paper, I examine the social insurance participation of a group of Japanese female part-time workers using microdata. There are four main conclusions. First, there has been an increase in social insurance partici- 
pation by female part-time workers from 1990 to 1995 . This increase is a result not of changing labor supply behavior, but of increased policy compliance and higher participation by those for whom enrollment is not mandatory. Second, conditional on satisfying the participation conditions for EP and health insurance, married women are no less likely to participate in social insurance than single women. However, among those who do not meet the conditions for mandatory EP and health insurance, married women are significantly less likely to participate. The provision that married women can claim benefits from their husbands' coverage discourages participation by this group.

Third, participation in EI is not very high among those who work twenty to thirty hours per week and earn 0.9 million to 1.3 million yen. Even though EI has provisions for short-hour workers that mandate participation, these provisions may not be very well enforced. Fourth, participation by part-time workers who meet the conditions for mandatory EP and health insurance is unrelated to age. Older part-time workers are no less likely to participate than younger part-time workers. However, among workers who only partially meet these conditions, older workers are less likely to participate than younger workers. This latter finding is consistent with the hypothesis that paying benefits to older workers is more costly than paying benefits to younger workers.

\section{Appendix}

\section{The Cost of Paying EP Benefits for Firms with EPFs}

If a firm has an EPF, the EPF pays the earnings-related portion of public pension benefits (except for adjustments for inflation and wage increases).

The EPFs are firm pension plans that pay supplemental pensions for retired employees. The EPFs are closely linked to EP programs through a system called "substituting the payment of employees' pension (daikoseido)." ${ }^{33}$ The EP benefit has an earnings-related portion that is proportional to one's contributions at young ages. If a firm has an EPF, the earnings-related portion of the benefit (excluding the part for indexation to wage growth and inflation) is paid by the EPF of the firm. The present discounted value of the future benefits of an older employee is higher than

33. This had been mandated for the EPFs until March 2002. However, starting April 2002, the EPFs were allowed to transfer the obligation to substitute the payment of EP to the government. If the firm transfers, the argument here may not apply. But in 1990 and 1995 (the years for the data used in this paper), the EPFs were required to substitute the payment, so the argument here is applicable. 
that of a younger employee because the benefits for an old employee will be paid in the near future, whereas those for a young employee will be paid in the remote future. Therefore, for firms with EPFs, pension benefit costs of older employees are higher than those of younger employees. Other things being equal, firms may be cautious in hiring older workers because the burden of their pension benefits is greater.

\section{The Cost of Paying Health Care Benefits}

If a firm forms an HIS, the firm self-insures its employees and dependents younger than sixty-nine (inclusive). However, the insurance premium rate is not allowed to vary across insured workers within an HIS. Therefore, healthy workers pay more in premiums than they spend on health care, while less-healthy workers spend more than they pay. Given this structure, attracting enrollees with large health expenditures would weaken the financial condition of an HIS. Health expenditures are likely to vary considerably across individuals. Since old workers are less healthy than young workers, firms may be cautious about including old workers in the HIS. Firms may keep the working hours of old part-time workers low so that they do not have to include them in the firm's health insurance plan.

\section{Considerations for Part-Time Workers}

Conditional on enrollment, there is no difference in health care benefits and health insurance premium rates between full-time and part-time workers. In other words, full-time and part-time workers who participate in health insurance are treated the same.

There is an important difference between full-time and part-time workers in the firm portion of the EPFs. Part-timers are usually ineligible for corporate pension benefits (due to the way firms typically set up their corporate pension plan). However, part-time workers who work in a firm with an EPF must participate in the firm's EPF for the purposes of receiving the earnings-related portion of their pension. If a worker enrolls in the EPF for more than ten years, the earnings-related portion of her EP benefits are paid by the EPF (rather than the Social Insurance Agency). On the other hand, if an employee works for a firm for less than ten years, the earnings-related portion is not paid by the firm's EPF, but by the Association of Employees' Pension Funds (AEPF). However, when the worker leaves the firm, the firm pays the present discounted value of the earnings-related portion of the worker's future benefits to the AEPF. Since the present discounted value of future benefits are higher for older employees (because they will start receiving benefits in the near future), the pension cost for the firm in this case is higher for older employees. 
Table 12A.1 Social Insurance Participation by Industry

\begin{tabular}{lllcrrr}
\hline Year & $\begin{array}{c}\text { Marital } \\
\text { status }\end{array}$ & \multicolumn{1}{c}{ Industry } & $\begin{array}{c}\text { No } \\
\text { Insurance } \\
(\%)\end{array}$ & $\begin{array}{c}\text { EI } \\
\text { Only } \\
(\%)\end{array}$ & $\begin{array}{c}\text { EPH } \\
\text { Only } \\
(\%)\end{array}$ & $\begin{array}{c}\text { All } \\
\text { Insurance } \\
(\%)\end{array}$ \\
\hline 1990 & \multirow{2}{*}{ Married } & Manufacturing & 47.35 & 7.47 & 1.33 & 43.85 \\
& & Service & 72.45 & 3.81 & 1.02 & 22.72 \\
& & Wholesale and retail & 65.36 & 7.77 & 1.80 & 25.07 \\
1990 & \multirow{2}{*}{ Single } & Manufacturing & 18.27 & 4.23 & 1.59 & 75.91 \\
& & Service & 48.86 & 6.29 & 3.31 & 41.55 \\
& & Wholesale and retail & 33.54 & 6.25 & 4.34 & 55.87 \\
1995 & \multirow{2}{*}{ Married } & Manufacturing & 41.92 & 15.24 & 5.27 & 37.57 \\
& & Service & 50.74 & 10.14 & 10.23 & 28.89 \\
& & Wholesale and retail & 51.65 & 14.76 & 6.53 & 27.07 \\
& \multirow{2}{*}{ Single } & Manufacturing & 24.11 & 7.21 & 4.83 & 63.85 \\
& & Service & 32.59 & 5.68 & 10.50 & 51.23 \\
& & Wholesale and retail & 23.98 & 9.27 & 6.72 & 60.03 \\
\hline
\end{tabular}

Source: Author's calculations from the Ministry of Labor $(1992,1997)$ data.

Notes: $\mathrm{EI}=$ employment insurance; $\mathrm{EPH}=$ employees' pension fund.

\section{References}

Abe, Y., and F. Ohtake. 1997. The effects of income tax and social security on the part-time labor supply in Japan. Review of Social Policy, no. 6:45-64.

Feldstein, M., and A. Samwick. 1992. Social security rules and marginal tax rates. National Tax Journal 45 (1): 1-22.

Higuchi, Y. 1995. The economic consequences of protection policies for nonworking married women. In Economic analysis of protection policies for the "disadvantaged" (in Japanese), ed. T. Hatta and N. Yashiro, 105-219. Tokyo: Nihon Keizai Shimbun sha.

Ministry of Labor, Government of Japan. Various years. Annual report on employment insurance. Tokyo: Ministry of Labor.

- 1992. Report on the general survey of part-time workers' conditions, 1990 (in Japanese). Tokyo: Ministry of Labor.

-1997. Report on the general survey of part-time workers' conditions, 1995 (in Japanese). Tokyo: Ministry of Labor.

Nagase, N. 1997. Part no chingin ha naze hikui ka? Shoseido no ashikase (Why are part-time wages so low? Obstacles by institutions). Ochanomizu University, Graduate School of Humanities and Sciences. Mimeograph.

Statistical Bureau, Prime Minister's Office. 1984. Employment status survey, results for Japan 1982. Tokyo: Statistical Bureau.

Statistical Bureau, Management and Coordination Agency. 1993. Employment status survey, results for Japan 1992. Tokyo: Statistical Bureau.

Statistical Bureau, Management and Coordination Agency. 1998. Employment status survey, results for Japan 1997. Tokyo: Statistical Bureau.

Takayama, N. 1997. Public pension reform. In Income maintenance policies in an aged society (in Japanese), ed. Naohiro Yashiro, 119-36. Tokyo: University of Tokyo Press. 